words give a graphic picture of the operations :- " $\mathrm{M}$. Ch. Oltay followed the traces of the torsion balance and determined by means of his pendulums the differences in gravity between five stations. This voyage into the unknown, far from mountains and from all other irregularity in the distribution of [surface] masses, had a peculiar charm. As we marched over a quite uniform plain, our instruments continually revealed to us something that was hidden below, and we could always direct our steps so as to follow or to cross a series of masses, and in this fashion know them better and better." A bye-product of this work illustrates its remarkable delicacy. Newton had shown that the gravitational attraction upon units of mass of different substances is the same within one part in a thousand; Bessel reduced the limits of possible difference to one in sixty thousand. Baron Eötvös, with his torsion balance, has reduced them to one in a hundred million, and thus set at rest the disturbing doubt whether geodesists might not have to consider more than one geoid.

We have left little space for the other topics that came before the congress. Colonel Bourgeois' report on base measurements revealed a mistrust of invar wires which was not generally shared; the resulting discussion, however, revealed some difference of opinion as to the necessity of standardising these wires in the field, and as to the respective merits of wires and tapes; it was decided to publish an interim report on the subject as soon as possible. Mr. King, Dominion Astronomer, made the gratifying announcement that his Government had authorised the establishment of primary triangulation in Canada upon a strictly geodetic basis. Colonel Burrard, representing India, described the measures which had been taken to discover whether geologists are right in supposing that the Himalayas and Tibet are moving southward and crumpling up the Siwalik range from the alluvial plain. Mr. Keeling described the geodetic operations in Egypt, resumed two years ago by the Government of H.H. the Khedive, " after a regrettable interruption of twenty centuries." Dr. Backlund and Dr. Carlheim-Gyllensköld gave a further account of the geodetic operations in Spitsbergen. Colonel Bourgeois described the re-measurement by the French Academy of the historical " arc of Peru." Prof. Hecker reported on his determinations of gravity over the Black Sea, on a vessel put at his disposal by the Russian Government. There is a somewhat remarkable circumstance connected with these investigations. On his earlier voyages he omitted to take account of the alteration in gravity produced by the E.-W. motion of the ship. Baron Eötvös pointed out the omission, and Prof. Helmert showed from Hecker's observations that the correction appeared to make otherwise concordant observations discordant; hence, he said, the theory appears to be incomplete. Prof. Hecker finds, however, from his Black Sea observations that the correction in question is certainly required. It remains to be explained why the former observations were accordant without it. Prof. Helmert has undertaken that the whole shall be rereduced.

The somewhat severe and technical labours of the congress were relieved by pleasant social functions, which were, however, kept strictly within bounds, and not allowed to become the burden which the festive side of a congress is too apt to be. On September 22, Sir George Darwin, representing the British Government, gave an official dinner to the principal delegates. On September 23, the president of the Royal Geographical Society took the whole party to Greenwich by water for a visit to the Royal Observatory and the Royal Naval College. On September 24, the Treasurer of the Royal Astronomical Society and Mrs. Hills were NO. 2084, VOL. 8I]
"At Home" at 32 Prince's Gardens. On September 25 , the delegates and their ladies visited Windsor, on the gracious invitation of the King. On September 26 many of them visited the National Physical Laboratory.

On Monday, September 27, the congress moved to Cambridge, where those unaccompanied by ladies enjoyed the hospitality of Trinity, St. John's, and Caius Colleges, and many others received private hospitality. On September 28. Sir Robert and Lady Ball were " At Home" at the Observatory in the afternoon, and Sir George and Lady Darwin gave an evening party in St. John's College. The final meeting was held on Wednesday, September 29, and in the evening the visitors entertained their Cambridge hosts to dinner Thus ended an exceedingly valuable, successful, and pleasant meeting.

\section{THE ADMINISTRATION OF AGRICULTURAL EDUCATION}

A MEMORANDUM has just been issued setting out the arrangements which have been made between the Board of Agriculture and the Board of Education in regard to agricultural education. It has been known for some time that a certain amount of controversy existed between the two departments on account of the anomaly arising from the fact that the Board of Agriculture inspected and gave grants to the various agricultural colleges and other institutions for higher agricultural education, whereas agricultural instruction in secondary and primary schools, like all other forms of education, was controlled by the Board of Education. On the one hand it was felt that agricultural education could not thus be dissociated from the general system of the country; on the other hand, there was the danger that so special, and in many respects so weakly supported, a subject would never receive the attention it deserved without the fostering care of its own special department. The situation became more critical as it appeared that the Board of Agriculture, however anxious to retain its connection with the colleges, was unable to obtain the funds either to make adequate grants to existing institutions or to promote the creation of fresh colleges where they were needed. The two Boards appear now to have arrived at a compromise which still leaves the higher educational institutions under the charge of the Board of Agriculture, but also secures an interchange of views by the creation of an interdepartmental committee. The Board of Agriculture is to take charge of advanced schools of agriculture serving, as a rule, more than one local education authority's area, and taking students of an age of seventeen and upwards; under its charge also will be such special institutions as deal only with one branch of agricultural instruction, as dairying, forestry, \&c. As before, the Board of Education will be in charge of the agricultural instruction that is provided by the county councils and other local educational authorities, but it is not clear by which board, or in what way. pressure can be brought to bear upon the backward counties that are now doing nothing for organised agricultural education. For example, the East Sussex County Council uses part of its "whisky money" to maintain an agricultural college, which is further assisted by grants from the Board of Agriculture; the West Sussex County Council next door puts the whisky money to the relief of rates, and does nothing for agricultural education. The defect in the Board of Agriculture's administration has been the fact that it has been powerless in such cases; it could neither compel nor bribe such counties to do their duty, and what the public interested in such matters is anxious to know is how the new arrangement will be worked 
ts ensure a provision of higher agricultural education for farmers in all parts of the country, a national system that is not dependent on the caprice or the poverty of any county council.

The novel feature in the memorandum besides the Inter-Departmental Committee is a proposal to create a Rural Education Conference, consisting of representatives of the County Councils' Association, the Agricultural Education Association, and other agricultural organisations, with certain officers of the two Boards. Such a consultative committee seems to smack of the Board of Agriculture's favourite attitude of asking the farmers what it can do for them, but perhaps the influence of the Board of Education, which takes a less humble view of its own expert qualifications and powers to give a lead, will supply the stiffening and find a means of translating the suggestions of the conference into practice.

\section{SCIENCE TEACHING IN GERMAN SCHOOLS.}

$\mathrm{THE}$ habit of self-depreciation, or at any rate the latest manifestation of it, which is now so prominent a feature of our national life, can be traced to its beginning in a general dissatisfaction with our system of education. At a time when there was no misgiving as to the superiority of our navy, when our commercial supremacy was still unchallenged, and when no foreigner dared to be our rival in the world of sport, it was nevertheless felt that in the science of education we had much to learn from abroad. If our secondary schools, especially the great " "public schools," were allowed to have been successful in the formation of character, yet the intellectual equipment of those who passed through them was, and still is, held by many to be miserably inadequate. Germany, on the other hand, is regarded as the land, par excellence, where not only the schoolmaster knows and does his business, but where a parental Government has elaborated an almost ideal system of mental training. It is interesting, therefore, to hear that in one important province of school work-the teaching of natural science-there is another side to the picture.

Dr. Erich Leick 1 finds it necessary to bring before the minds of the German public certain points that with us for some years have been received as axiomatic, and are no longer discussed. In England we believe and act on the doctrine that no scheme of education, even for the children of well-to-do classes, should omit all reference to the living world of nature. It is, moreover, generally agreed that courses of practical lessons where common objects are studied by each pupil form the best means whereby the power of observation, clearness of expression, and the inductive methods of science can best be acquired, let alone a general interest and love for living things. Yet in Germany up till now, so we learn from Dr. Leick, natural-history lessons, if given at all in the secondary schools, have been of the old didactic kind, in which the teacher lectures almost entirely for one, or at most two, school hours in the week, and practical work is conspicuous for its absence. This seems to hold good for other branches of science, especially in the classical gymnasia, where, as Dr. Hoppe 2 tells us, practical work in physics is not insisted on, and is done only by "Freiwillige." His pamphlet, in fact, is written to show that some boys will do laboratory work out of school if allowed, and he gives hints as to the best exercises for such volunteers.

1 "Die biologischen Schülerübungen." By Erich Leick. (Leipzig: Quelle and Meyer, T909.)

"Freiwillige Schülerübungen in Physik in humanistischen Gymnasien." By Prof. Dr. Edmund Hoppe. (Leipzig: Quelle and Meyer, Igog.) NO. 2084 , VOL. $8 \mathrm{I}]$
It need scarcely be said that thoughtful teachers in Germany are dissatisfied with this state of things, and it is gratifying to read in Dr. Leick's account that the example of England is gradually affecting German science teaching. In fact, anyone who has read $\mathrm{Mr}$. O. H. Latter's article on the teaching of science in secondary schools, recently published as an educational pamphlet by the Board of Education (see Nature, August I2, p. I92), may well rub his eyes with astonishment at the antiquated systems still prevailing in many of the German Gymnasien and Realgymnasien compared to those of our own schools. Is it too much to hope that our improved methods of teaching may bring forth fruit in the next generation, and do much to remove the reproach we are constantly hurling at ourselves that we are an unscientific nation?

The limits of this notice forbid a discussion of either of these interesting pamphlets. Suffice it to say that Dr. Leick, after a review of the gradual introduction of inductive methods into the study of natural science, describes the ups and downs that biological teaching has met with in Germany, and acknowledges the part played by the authorities of Hamburg and Bremen in insisting on natural history being taught in their schools. He shows clearly enough the kind of mental training that biology alone can give, although he is no revolutionary who would sweep away humane letters out of the field. Especially noteworthy is his tactful reference to the problem of sex, how it can best be dealt with by natural-history lessons in the hands of a sympathetic teacher. Doubtless the details of his scheme invite criticism, especially the use of the compound microscope by young pupils, but they offer food for thought to all who have to teach his subjects.

Dr. Hoppe's little work may be well offered to those classical masters in our public schools, if such there be, who still believe, like Darwin's headmaster, that natural science is a waste of time, and have forgotten in their zeal for grammar the true spirit of inquiry of the ancient Greeks. Teachers of practical physics may gain some useful hints from his list of exercises.

But, as has already been suggested, the chief interest to British teachers in these pamphlets lies in the fact that they give us glimpses of what we should not have suspected in so scientific a country as Germany. 'They confirm the present writer's impression after hearing a science lesson in a German Realschule, that the boys were standing aside and watching rather than taking off their coats and joining in the work themselves.

M. D. $\mathrm{H}$

\section{ANTON DOHRN.}

THE whole biological world will feel a pang of grief at the news of the death of Anton Dohrn, the founder and director of the Zoological Station of Naples. It is true that he had accomplished the great work which he set himself forty years ago, and had seen the projects and dreams of his youth fully realisedand more than realised. I met Dohrn first in 1870 at Liverpool, when Huxley was president of the British Association, and in May and June of the next year went, after a winter spent in Leipzig, to join him at Jena, where he was a "privat-docent" in zoology. He was then thirty years of age, and had done some excellent embryological work on the Crustacea, in furtherance of which he had passed some months at Naples and Messina. His father, with whom I later spent some weeks at Naples; was a very remarkable man, one of the iron-willed, somewhat grim type of North Germans, a handsome old gentleman, known throughout Europe as a great collector of Coleoptera, 